\author{
Edvin Østergaard \\ Norwegian University of Life Sciences
}

DOI: http://dx.doi.org/10.5617/adno.6452

\title{
Music and sustainability education - a contradiction?
}

\begin{abstract}
Sustainability education is an interdisciplinary endeavor and should thus include music as well. In this paper, I explore the under-researched field of music and sustainability education. My central thesis is that music and attentive listening have a potential of strengthening students' aesthetic experience and world bonding, two essential elements of their sustainability engagement. The paper consists of a review of research on art, music and sustainability education, an elaboration on eco-acoustics and efforts to apply music to the sonic world, and a discussion of the training of music-sustainability competencies. In the existing research on music and sustainability education, I find a latent tension between those who regard music as a means for teaching for sustainability, and those who view music as genuine knowledge that there is need of in sustainability education. Perhaps the greatest fallacy is to reduce music to a mere tool to reach sustainability goals. Then music's aesthetic and creative potential is lost. We need fresh and unconventional ideas to cope with the present situation in a desirable future direction. Listening as world engagement, I discuss in relation to the skills of doing music: listening to music, performing music, and making music. I argue that there is much to learn from soundscape artists when it comes to refining students' ears for the environment's sonic expressions. Such a refinement presupposes, however, an interdisciplinary commitment in school of practicing the skill of listening, also in other subjects than music.
\end{abstract}

Keywords: music, aesthetic experience, attentive listening, sustainability education

\section{Musikk og utdanning for bærekraft - en motsetning?}

\section{Sammendrag}

Utdanning for bcerekraftig utvikling forutsetter tverrfaglig samarbeid og skal derfor også inkludere musikkfaget. I artikkelen diskuterer jeg musikkens potensielle rolle i utdanning for borekraftig utvikling, et til nå lite utforsket tema. Min antakelse er at musikk og oppmerksom lytting har potensial til å styrke elevers 
estetiske erfaring og forbundethet med verden, to forutsetninger for deres engasjement for en baerekraftig fremtid. Artikkelen består av en gjennomgang av eksisterende forskning på kunst, musikk og borekraft $i$ undervisningen, en drøfting av øko-akustikk, musikk og oppmerksom lytting, og en diskusjon av oppøving av kompetanser som er felles for musikk og utdanning for barekraft. Min utforsking av eksisterende forskning viser en latent spenning mellom dem som anser musikk som et middel $i$ undervisning for barekraft og dem som oppfatter musikk som genuin kunnskap for en boerekraftig utvikling. Dersom musikk gjøres til et rent redskapsfag for å nå borekraftmålene, går dens estetisk-kreative egenart tapt. For å bevege oss mot en boerekraftig fremtid trengs ukonvensjonelle ideer og djerv handling. Lytting som estetisk erfaring diskuterer jeg i forhold til musikkfagets tre kompetanser: å lytte til musikk, å fremføre musikk og å lage musikk. Jeg argumenterer for at det er mye å loere av soundscape-kunstnere når det gjelder å oppøve elevers evne til å bli var omgivelsenes lydlige uttrykk. Oppøving av en oppmerksom lytting forutsetter en tverrfaglig vilje $i$ skolen til å øve lytteevnen, også $i$ andre fag enn musikkfaget.

Nøkkelord: musikk, estetisk erfaring, oppmerksom lytting, utdanning for borekraftig utvikling

\section{Introduction}

In their review paper Music and sustainability, Kagan and Kirchberg (2016) claim that a specific focus on music lacks in sustainability science. Whereas several projects combine the visual arts and sustainability teaching (e.g., Lutnæs \& Falling, 2017; Pröpper, 2017; Jolly, Boeckel, \& Slåttli, 2017), only rarely we find research projects on the intersection of music and sustainability education. When art is included in STEM subjects (as STEAM), the attention seems to be primarily on visual arts and media, not on the performing arts and music (Gershon \& BenHorin, 2014). The emerging field of arts-based environmental education has merely a gradated attention toward music and the sonic world compared to the visual arts (e.g., Boeckel, 2013). Also, art projects on sound and eco-acoustics for example field recordists and soundscape artists (e.g., Samkopf, 2010) - seldom relate to learning or school curriculum dimensions. These facts motivate me to ask whether there is a contradictory relation between music and sustainability education. Music also lacks in the emerging field of aesthetics in science education. In for instance Exploring Emotions, Aesthetics and Wellbeing in Science Education Research (Bellocchi, Quigley, \& Otrel-Cass, 2017), the keywords "music" and "listening" lack in the index.

I enter the under-researched field of music and sustainability with a particular focus on potentially beneficial relations between music and sustainability topics and competences. The central thesis in my inquiry is that music and attentive 
listening have the potential of strengthening students' sensuous awareness and world engagement, two essential elements of students' sustainability engagement. I discuss the thesis related to interdisciplinary efforts for teaching sustainability. With a background in pre-service science teacher education, I use a few times science education as a focal point in my discussion.

Before proceeding, I briefly dwell on some key concepts. The word music I use in connection to the three activities listening to music, playing music, and composing music. Attending to music - or "musicking," a term coined by Small (1998) - is connected to training and performing skills, particularly the skill of listening. Whereas hearing is receiving sound with the ears, listening is a practice of audial engagement and presence. Hearing is one of our physical senses, whereas listening requires focus and attention. Listening is not limited to music; it is continuously employed in our everyday lives. Further, I use the term sustainability in its broadest meaning, as a paradigm for a future "in which environmental, social and economic considerations are balanced in the pursuit of development and an improved quality of life" (UNESCO, 2012, p. 5). Education for sustainable development concerns "social transformation with the goal of creating more sustainable societies” (p. 33). I use sustainability education as the term comprising educational efforts that promote a variety of students' skills toward a sustainable sound future. Finally, I consider human sustainability from an existential perspective, as being rooted, being grounded, and having a sense of belonging. When I talk about competences, I use it in the sense of "a functionally linked complex of knowledge, skills, and attitudes" (Wiek, Withycombe, \& Redman, 2011, p. 204) as abilities that are performed and can be trained.

My inquiry rests on four pillars. The first is that sustainability in education is profoundly an interdisciplinary endeavor and should thus embrace all school subjects (Clark \& Button, 2011; Sterling, 2014). In my discussion, I emphasize interdisciplinary efforts to improve attentive listening in education, a competence I argue could strengthen students' world bonding. In the Norwegian Science curriculum, the noun "listening" is not found, whereas "hearing" is mentioned twice: Under the heading Competence aims after Year level 7, it is stated that " $t$ t]he aims of the training are to enable the apprentice to investigate phenomena related to sound, hearing and noise, discuss these observations and explain how sound can damage hearing" (Udir, 2019c, p. 9, italics added). This narrow understanding of hearing excludes essential aspects of the listening ability. In this article, I explore the possibilities of interdisciplinary collaborations on attentive listening between school subjects, for example science and music education.

Secondly, we need to consider the complex character of sustainability problems. In addition to severe environmental problems and challenges that we currently face, sustainability also has epistemological dimensions. Kagan (2012) argues that the true sustainability problem is the atomization of knowledge as it represents a severe hindrance for cultivating our sensibility toward the complexity of the world. Technology-mediated experiences, Kagan maintains, might 
generally contribute to numbed experiences of both nature and culture. In line with Kagan's argument, Pröpper (2017) argues that sustainability science "is facing a crisis of agency and collaborative knowledge production” (p. 7). Twentyfive years ago, Orr (1994) claimed that "the crisis we face is first and foremost one of mind, perception, and values” (p. 27). If perception deficits enhance the environmental crisis, how can school reinforce students' perceptual, sensuous skills and experiences? Moreover, if the problem of sustainability is one of values, how does education critically reflect and creatively promote values that form the basis for more sustainable futures?

A third perspective concerns students' diminished ability to relate to the environment. Several science education scholars point to the current situation characterized by students' experience of being de-rooted and alienated (e.g., Roth, 2015; Colucci-Gray \& Camino, 2016). Recent studies from Germany show that young persons are increasingly detached from nature (Brämer, Koll, \& Schild, 2016). When 12- and 15-year-old students in 2016 are asked about what they prefer to do outside, only $29 \%$ answer "walk alone through the woods" compared to $53 \%$ in 1997 . To the question "Where does the sun rise", 35\% of the 2016 students answer "east" compared to 59\% in 2010. It does matter for the students" understanding of both nature and their active participation in sustainability discourse whether they have a grounded relation to nature and are accustomed to being outside. If nature detachment and alienation is a problem in education toward sustainability, then the problem cannot be faced solely theoretically, it must be dealt with pedagogically as well. Rooting and a sense of caring is promoted by meaningful activities in authentic environments. What you care for, you tend to protect (Østergaard, 2017).

The fourth pillar of this inquiry is my interest in researching musicsustainability issues. With a background in science teacher education and musical composition, I have wondered what the reasons might be for the apparent reluctance of music education concerning sustainability issues. One obvious reason is the subject-related differences in prioritizing the topic in various curricula. Whereas sustainable development is mentioned several times in the science curriculum throughout ten grades (Udir, 2019c), the issue is not at all mentioned in music curricula (Udir, 2019a, 2019b). It is unfortunate that music with its rich tradition of close listening and aural attendance - in a sustainability setting often is missing. For me, listening to music, listening to birds sing, listening to a friend talk, and listening to the becoming of a musical composition, are all forms of paying attention. In a sustainability perspective, the challenge seems to be a matter of increased sensuous awareness and participation in the environment. If the goal is, I ask myself, to promote students' presence and active participation in the world, which role may music and attentive listening play?

The paper is structured around three main elements: (i) a review of existing research on art, music and sustainability, (ii) an elaboration on efforts to apply art 
and music to the sonic world as eco-acoustic awareness, and (iii) a critical discussion of the potential of training music-sustainability competences.

\section{What can research tell us about art, music, and sustainability?}

Based on a search of databases, including a search of scholarly, professional, and artistic research literature, I now present papers discussing the role of art and music in sustainability and environmental education. I start by sketching the expanding field of art and sustainability. I intend to place music within this field and thus broaden the ground for discussing the contribution of music and attentive listening to sustainability education.

\section{Art and sustainability}

In highlighting the diverse combinations of art and sustainability, Pröpper (2017) states that contributions from art involve both experimental and experiential approaches to knowledge production. Art represents much more than means to aestheticize science's content and processes. Thus, art should play an active role in connecting "knowledge, morality, beauty, and everyday life [...] as constitutive elements of sustainable behavior” (p. 7). Clark and Button (2011) maintain that art is essential when it comes to promoting "critical inquiry of environmental awareness and sustainability” (p. 42). By drawing connections between aesthetics, science education, and sustainability education, Kagan (2011) claims that art can bond the experiencer with the world as a greater pattern. Being aesthetically sensitive toward the world means to be able to recognize and understand its complexities. An expanded experience of reality can be "achieved through a heightened sensibility (to patterns that connect, to complexity and to the morethan-human lifeworld in general)” (p. 218). And:

[T] he contributions of art to a culture of sustainability is to be found especially in its potential to create experience, make relationships, expand mental activity beyond the linear confines of purposive consciousness. (p. 218)

An aim of art-based environmental education is to promote an ecological awareness through art practices (Boeckel, 2013). The intention is to foster students' sensibility toward the environment and to strengthen their embeddedness in the world.

The school subject arts and craft comprises practical problem solving and aesthetic experiences, elements that are relevant for sustainability teaching (Lutnæs \& Falling, 2017). In the aesthetic experience, the students are brought in contact with sustainability themes both emotionally and intellectually. The work of art "has the power to make the invisible visible by making abstract phenomena concrete in visual presentations" (p. 15, my translation). While discussing a case of biology teaching combined with art-based activities, Jolly, Boeckel, and Slåttli 
(2017) report a positive effect of training observation skills. Sketching plants is more than merely looking and drawing: "The idea behind the drawing exercise is to reconnect the students with nature and provide them with new experiences, beyond what they already think and know" (p. 12). Based on feedback from the participating students, the authors claim that "students establish a closer connection to nature and become more aware of our collective responsibility to take care of it” (p. 17).

An art-science approach in education enables a critical reflection on our interactions with nature (Kagan, 2011). This approach criticizes the tendency to reduce the value of nature to a matter of man's self-constitutive activities. Art critically questions the constructivist predominance in current educational discourse. The artist has an open ear for the value and character of nature, or the nature of nature (Dahlin, Hugo, \& Østergaard, 2015). Whether students know how to define nature scientifically or they know how to express their relations to nature, depends eventually on their conception of nature. An artist's openness invites nature to speak, in its multiple languages, dialects, and accents. Sustainability is also a matter of nature-relatedness.

\section{Music and sustainability education}

With an understanding of art as aesthetic, sensuous awareness rather than an outcome of artistic production, I now turn to the role of music and attentive listening in sustainability education. Kagan and Kirchberg (2016) present a first overview of research on music and sustainability. They claim that both music as a social experience and the practice of music can contribute to the cultural dimension of sustainability. I am here especially concerned with their understanding of aesthetics of complexity, which they define as "a sensibility to the amazing dynamic complexity of the living world surrounding us and of humans as individuals, as a society and as a species” (p. 1493). Music can, they maintain, develop and foster alertness and sensibility toward the complex structures of nature. Does the training of a discerning ear in music education, especially in instrumental music, help students "to perceive the complexity beyond a first step of pattern recognition" (p. 1493)? And, if yes, may the ear also be applied to non-musical sounds, as the joyful chirping of birds an early morning in May or the cacophony of a city soundscape? The authors argue that music represents a potential for sustainability transformation, a potential that is largely untapped by the sustainability community.

When discussing the role of music in environmental education, both Ramsey (2002) and Publicover, Wright, Baur, and Duinker (2018) focus primarily on music as a carrier of lyrics about ecosystem fragility and environmental topics. The music itself, or left alone its educational aspects, is not the focus of their inquiries. Similarly, a study on the use of music in environmental education focuses on musical lyrics to inform students about environmental issues as "the educational niche of music is one of helping students to develop a sensitive 
attitude to environmental and related issues” (Turner \& Freedman, 2004, p. 50). Coss (2013) discusses the multicultural perspectives of music and sustainability education and maintains that the specific character of musical experience "lies in its focused engagement with the world of sounds, as opposed to strictly visual, textual, or movement-based experiences" (p. 21). He emphasizes the importance of keeping the uniqueness of musical experience at the forefront when music education focuses on multicultural issues.

When music is incorporated into science and mathematics education, music tends to be regarded as a means for scientific learning and not in itself a genuine form of knowing. Burnard et al. (2017) report from a project in primary school where music is used in teaching mathematics. Even with the intention of supporting students' "musico-mathematic knowing", the role of music is primarily to promote students' understanding of numbers and counting by "hearing mathematics" (p. 274). The same tendency is found when music is combined with teaching sustainability issues. Clark and Button (2011) describe a teaching unit about sustainability using a combination of visual art, music, theater, and nature sounds. A musician was invited to create "musical bird sounds to model a story" (p. 45). Second-grade children were then encouraged to create bird-like sounds, both of those they knew and those they imaginatively invented before they wrote down their stories. The authors found a need for both children and teachers "to experience artists and creative environments to illicit critical and creative thinking for sustainability" (p. 46). Here, music is for the children an entrance into formulating their experiences verbally and training their thinking skills.

Merely three of the reviewed research papers touch explicitly upon music and sustainability education. In addition, three research projects deal with music in environmental education. Among these six, only Coss (2013) discusses music as a genuine contributor to students' sustainability learning. These studies all, however, indicate a potentially non-contradictory relation between music and sustainability education. There is in principle no conflict when it comes to integrating music in sustainability teaching. Further, none of these research projects, including Kagan and Kirchberg's (2016) review, questions the ability to listen itself. Can we take for granted that listening skills are given, once and for all? The question of whether our ability of listening has decreased, and eventually whether this decrease constitutes a sustainability problem, ought to be researched. Is our environmental crisis an expression of a particular kind of deafness, toward nature as well as ourselves as an integral part of nature? If this is the case, how do we go about this problem? In the following two sections, I elaborate on attentive listening as an entrance to discussing these questions. 


\section{Applying the musical ear for the sonic world}

There is much to learn from music when it comes to refining students' ears for the manifold of the environment's sonic expressions. Such a refinement presupposes, however, a reflective understanding of the ability to listen. Music philosophers are engaged in exploring the phenomenon of audial attention; its characters, its conditions, and its power of opening a world. In Listening to Music, Morton Evans (1990) claims that commonly the focus of attention is drawn toward the object of listening, rather than the activity of listening itself. If we start investigating the listening act, it seems ...

[...] that two alternative pictures of the listener emerge, between which we must arbitrate. The one is of a passive recipient of the sensations that come his way; the other is of someone actively engaging in what he hears. (p. 12)

The active listener practices the ability "to engage in music in a directed way. He participates in what he hears. The music will not of itself speak to him - he must read it” (p. 13). Compared to a view of active listening, the presentation in science textbooks is primarily on the knowledge about sound structures. There is usually no focus on our ability to hear the sounds. When at all listening is mentioned, it is either about hearing loss, the effect of noise on the hearing ability or the biological structure and function of the ear. The human ear is depicted as a passive recipient of sound waves. Also in educational research, the skill of listening is often neglected. Active listening is for example by McNaughton, Hamlin, McCarthy, Head-Reeves, and Schreiner (2007) not described as actively applying one's ear to the sounds of the surrounding, but rather as "making emphatic comments, asking appropriate questions, and paraphrasing and summarizing for the purposes of verification” (p. 224). In contrast, listening as an active process is developed in music psychology (e.g., Hargreaves, Hargreaves, \& North, 2012), music history (e.g., Erlmann, 2010), existential philosophy (e.g., Espinet, 2016), and, as I discuss later, by modern composers such as John Cage.

The idea of listening as world engagement is developed by Martin Heidegger (1962). Sense experiences, Heidegger maintains, form the foundation upon which our meaningful acquaintance with the world rests, even though these experiences remain for the most part unreflected. Among sense experiences, listening takes a unique position in Heidegger's early philosophy. Through listening, we are inthe-world. Heidegger's argument is opposed to a view of the sequential order of acoustic events; that first the sound is produced, then transmitted from its source to the ear, and subsequently transformed into meaning. Existentially speaking, listening is not monitoring of wave compressions that reach the ear from an acoustic source, which we then make sense of. On the contrary, in our participating listening, we are already alongside the events and their meaningfulness: "What we 'first' hear is never noises or complexes of sound, but the creaking waggon, the motor-cycle” (p. 207). The listener attends actively to 
sounds, and at the same time, the world appears generously as sounding events for the listener.

Listening as world engagement, as being-in-the-world, is related to John Dewey's ideas of experiential learning. In his influential work Art as Experience (2005, first published in 1934), he proposes a shift of focus, from the aesthetic experience of the art object - or, for that matter, of objects in nature - to the act of experience itself. The object of attention, that be of art, music or nature, is incidental; the primary focus is on the uniqueness of the experience itself. An aesthetic experience, Dewey argues, is the sensation of being-one-with, it is the unification of person and environment. In the aesthetic experience, the listener and the sound itself are one. There is no distinction between observer and observed in the aesthetic experience "in which the two are so fully integrated that each disappears” (Dewey, 2005, p. 259). Dewey's elaboration on the sensation of being unified is relevant for my upcoming discussion of the skill of world connectedness.

The composer, avant-gardist, and writer John Cage is renowned for expanding listening from music performance to the sounds of the environment. In his iconic composition 4'33" for solo piano from 1952, Cage in a radically new manner guides the listener's attention toward the ambient sounds. By not playing a single tone throughout the piece, the pianist forces the audience to listen to the surroundings. Their attention is drawn toward the act of listening on the one hand and the "music" of the surroundings on the other. In both his writings and his music, Cage broaches the issue of how we employ our ears to listen to the world's audial richness. Cage's ideas conform to both Böhme's (2001) notion of acoustic sensuousness as heightened awareness for the world's sounds and Kagan and Kirchberg's (2016) ideas of aesthetics of complexity.

One of Cage's intentions is thus to teach people how to listen (Peters, 2018). He rejects the possibility of using music to reinforce listening to the surroundings. On the contrary, music, as it is usually heard, tends to get in the way of listening. With reference to modernism's emancipatory dimensions, "Cage's work is a freedom-from musical listening coupled with a freedom to truly hear what is there to be heard” (p. 3). Cage claims that the purpose of music is not to support some logical activity, but rather "[t]o draw us nearer to the process which is the world we live in" (Cage, 1981, p. 81). This perspective is especially relevant for my focus on music, attentive listening and strengthening of students' world grounding.

John Cage aims at liberating sound from an inherent musical meaning by opening up our ears for the diversity of the world's sounds. His aim is in accordance with the currently increasing attention toward the fields of acoustics and ecology - the topic of the next section. 


\section{Toward an eco-acoustic awareness}

Listening as part-taking in the world has two dimensions that are intimately related. Active listening means, on the one hand, intentionally stretching out to the world, seeking its multiple voices actively. On the other hand, listening is receptively to let the world sound with its multiple voices. The ontological question of the character of the sounding nature, I have briefly touched upon and return to again later. Here, I sketch the field of eco-acoustics and its attempt to develop environmental bonding through intentional listening.

Dewey's notion of aesthetic experience as the merging of person and object is akin to Gernot Böhme’s (2001) interpretation of Aisthesis. For Böhme, acoustic sensuousness means aesthetic perception and awareness and the "discovery of musicality in the world itself" (p. 43, my translation). When inquiring about the acoustic atmosphere, Böhme advocates a new audial aesthetics rooted in the sense of listening itself, independent of the object of listening. The aesthetic experience establishes a space in which "the listener senses tone, voice, and noise as modifications of the space of his or her own presence” (p. 47, my translation).

A soundscape is an environment as we hear it; it is "a perpetual and dynamic property of all landscapes" (Pijanowski et al., 2011, p. 203), it is "the totality of the sounds occurring at any location within a certain time frame, including those that are biological, geophysical, and anthropic" (Gasc, Francomano, Dunning, \& Pijanowski, 2017, p. 216). The composer David Dunn theorizes about the role of sound in environmental awareness. He advocates the necessity "to hear beneath the surface of our most familiar projections to what might be a more intrinsic understanding" (Dunn, 1999, p. 28). This form of hearing he refers to as "serious listening"; it is "an active, questioning process" based on a theory of listening which aligns him with John Cage's use of ambient sounds in musical compositions (Ingram, 2006, p. 126). For Dunn, "serious listening” is helping to "renew our sense of hearing"; it is a way of listening that "plays a vital role in healing our alienated relationship with nature" (p. 128). Here, Dunn connects the skill of listening to efforts to strengthen our being-in-the-world.

Soundscape artists work with both recording environmental sound and composing dialogues between man and nature. Kjell Samkopf (2010) shows how thinking about soundscape compositions is similar to composing a piece for musical instruments. His soundscape compositions often take the form of an interplay between human-made sounds and those of nature. In Mårådalen Walk from 1994, Samkopf has recorded the sounds as he walks on stones by the water, in the delta below the glacier, and up an engraved straight line in the snow in the Norwegian valley of Mårådalen. What we hear in the recording is humans-nature interactions in an audial form. Similarly, Music for Large Mountain and Vibraphone from 2002 is a playful comment on the conventional concert form. Here, Samkopf acts as a vibraphone soloist in the midst of the ambient mountain sounds. 
The kinship of sound studies and ecology has given rise to several new disciplines. The field of eco-acoustics is an approach to investigating ecological issues through environmental sounds (Sueur \& Farina, 2015). Whereas bioacoustics is primarily an animal behavior discipline that studies sound signals between individuals, eco-acoustics "considers sound to be a component and an indicator of ecological processes" (p. 494). The interdisciplinary field of soundscape ecology includes bio-acoustics, landscape ecology, community ecology, and engineering. Its principal questions are related to "the interaction of the biological, geophysical, and anthropic components” (Gasc et al., 2017, p. 216). Through the investigation of the world of sound, a whole new range of concepts emerge: The term biophony describes the sounds created by organisms, geophony encompasses non-biological ambient sounds, i.e., wind, rain, and thunder, whereas anthrophony is sounds caused by humans. Further, soundscape ecology is described as "all sounds, those of biophony, geophony, and anthrophony, emanating from a given landscape to create unique acoustical patterns across a variety of spatial and temporal scales” (Pijanowski et al., 2011, p. 204).

There are many different entrances into the emerging interdisciplinary field of ecology, acoustics, and soundscape. The field is characterized by the scientific exploration of sounds in the environment, not the ability to listen to the sounds. How are the eco-acoustic perspectives relevant to music, sustainability education, and attentive listening?

\section{Music-sustainability competences}

In my inquiry, I emphasize the skills of doing music: listening to music, performing music, and making music. Common for all three areas of "musicking" (Small, 1998) is the skill of attentive listening and aural attendance. My emphasis on training skills is in line with the shift in educational discourse, from "what knowledge has to be acquired" to "what competencies should be developed" (Sterling, Glasser, Rieckmann, \& Warwick, 2017, p. 160). I will now more closely discuss possible links between musical skills and sustainability competences.

\section{Listening to music}

Music as attentive listening, Kagan and Kirchberg (2016) maintain, offers an "aesthetic training in the experience of complexity for the person who stimulates their 'musical ear'” (p. 1495). Can musicians make their refined listening skills available in science learning, for example in acoustics in physics class, or birdsong in biology class? The authors claim that ear training "would allow a discerning ear to perceive the complexity beyond a first step of pattern recognition” (p. 1493). Does the listener employ the ear differently when listening to an orchestra piece with its complexity of instrumental sounds and musical 
structures compared to listening to compound sounds of birdsong in the woods an early morning in spring?

I have only found a few studies dealing with the question of whether the skill of musical listening is transferable to other contexts. In a longitudinal empirical study over five years, Bastian (2000) finds that practicing musical skills do indeed lead to significant improvements in the science students' social competences. It did not, however, improve their results in tests for subjects like science and mathematics. This finding does not necessarily exclude positive listening correlations between music and science education. It does indicate, though, that achieved abilities in distinct subjects are not readily transferable to other subjects. Listening with a discerning ear to complex musical structures is not per se applicable to other listening situations. Learning aural attentiveness in the concert hall does not per se strengthen attentiveness to sounds of a soundscape. We should, however, not all together exclude the possibility that music listening can be transformed into soundscape listening.

It is not a matter of course that musicians and composers, who daily engage in listening, can employ their ears for sounds that are not music. John Cage somewhat laconically noted that even though composers have ears for music, they do not hear anything else than their own music: "Their ears are walled in with sounds of their own imagination" (Cage, 1961, p. 155). Perhaps the same could be said about music teachers listening to something else than music. When improving the ability to listen, the ability should be trained in that specific context where the sounds are at home; in the woods, in the concert hall, in the city environment.

\section{Performing and making music}

Playing and singing together is essentially the training of one's active partaking in a musical whole through "listening and tuning in to each other" (Kagan \& Kirchberg, 2016, p. 1499). Playing together strengthens social attentiveness and communication skills, it reinforces a profound sensation of being-with-oneanother. Musical interplay is a social activity and shared practice that enhances group cohesion.

When it comes to composing music, especially the skill of creativity is fostered, Gershon and Ben-Horin (2014) argue, because "engaging in processes of making music can help students more deeply engage in the kinds of creativity associated with inquiry based science education" (p. 1). Inquiry-based approaches in learning science and making music are both critical and creative activities. The authors maintain that "processes of making music helped to foster an important and paradoxical-seeming aspect of inquiry, the liminal moment of simultaneously being lost in the process and completely present in that moment" (p. 3). Here, we find a link to sustainability education, where creativity and visioning lie at its core.

The skills of creativity and listening and tuning in to each other are all vital for educating the properties of being sustainable. A direct transfer of the skills from 
music to science and sustainability education would have been desirable. However, is such a transferability possible? And, if yes, how do teachers collaborate to utilize these skills in the different subjects?

\section{Music and openness}

Musical skills should not be valued solely as tools to achieve specific learning goals in sustainability education - or in general education for that matter. Might open listening in Cage's interpretation play a role in sustainability education? Open listening and being in the mode of not-yet discovery may play an important role if we take as a starting point, as Böhme (2001) advocates, an understanding of aesthetics as sensuous awareness and knowing. The training of attentive listening skills serves the purpose of becoming sensitive to the sonic richness of our environments. Music can stimulate and encourage "openness to the ambiguities [...] and creatively chaotic dimensions of reality" (Kagan \& Kirchberg, 2016, p. 1499).

Openness for what is and what might come, is of profound meaning for the artist. In both the artistic process and in the reception of works of art, there must be a certain degree of openness. Providing open spaces is perhaps the most significant contribution from the arts to sustainability education. To include openness in sustainability education, it seems that we need to liberate the training of listening abilities from a mere utilitarian approach (Østergaard, 2019). The critical task of today, Cage argues, is to learn to listen unbiasedly. To open ourselves up to the world, "we must consider the ecology even more than the individual. It is not simply by observing the individuals, but by reintegrating individuals into nature, by opening the world to the individual, that we will get ourselves out of this mess" (Cage, 1981, p. 56, italics in original).

\section{Listening and connectedness}

The three skills of doing music - performing, creating, and listening to music find their equivalents in the sustainability competences (Sterling, 2014; Sterling et al., 2017; Wiek, Withycombe, \& Redman, 2011). Performing music is an exercise in active participation in a larger whole. Creating music means creatively exploring and expressing what is and what the future might bring. Listening to music has a potential of creating openness toward the world's on-going and complexity. Together, these three skills form a potential foundation for developing music-sustainability competences.

According to Sterling (2014), sustainability competences are characterized by an anticipative perspective and future orientation, the abilities to think critically, creatively and systemically, an action competence, an ethical sensibility and an ability to manage in conditions of change. None of these competences are explicitly related to attentive listening, world bonding or connectedness. In a compilation of 52 competences in sustainability from selected peer-reviewed literature (Wiek, Withycombe, \& Redman, 2011, p. 208), the closest we come to 
such a sustainability competence is "participation". Participation might be both sensuous and aesthetical (with eyes and ears) and bodily (through actions) (Gjøtterud \& Krogh, 2017). Being competent in connecting with the world corresponds to a certain degree to "affinity for life", a skill that Glasser and Hirsh (2016) associate with such qualities as identification with all life, biophilia integration, and species-level humility (p. 129). The skill of connectedness is the emotional and intellectual ability to participate actively in natural and social environments as a whole person. It is the sensation of being here, now. To practice the skill of connectedness seems to be of profound meaning for shaping a sustainable future.

\section{Further research in the field of music and sustainability education}

The field of music and sustainability education is extensively unexplored, thus, there is a need for research on a wide range of topics. Among the reviewed works, I have found little empirical evidence that supports the conclusions regarding a fruitful relation between music and sustainability. It is from time to time difficult to distinguish between fact-based findings and wishful claims. In this section, I sketch three ideas for exploring the collaboration between music and sustainability education.

The aim of a potential empirical study is to generate knowledge about how science students and music students together develop understandings of nature and humans-nature interactions. With a soundscape approach, the study design consists of two parts, each part followed by a reflection exercise: The soundfield recording encourages students to record sounds around the school guided by the questions: What is the sound of nature to you? How does an interplay between humans, nature, and environment sound to you? By these recordings, the students together reflect on questions like: Do science students and music students hear the environment differently? What is there to learn from music students' listening capabilities? What is there to learn from science students' understanding of and attraction toward nature? The next part involves soundscape composition. Here, the students together combine recorded ambient sounds from the documentation part with instrumental or vocal music. By these compositions, the students together reflect on questions like: How can an interaction between humans, nature, and environment be "composed"? What does it imply to interact actively with the surroundings in a sonic manner? For the project to succeed, it presupposes a mutual interest from both music and science teachers.

A second field to be explored in depth is the skill of listening itself. When we say that we listen to Wagner - or to nature for that matter - hearing in itself is usually ignored. None of the research papers on music and sustainability that I have reviewed for this article focus on the ability to listen, left alone how to improve listening. If Orr (1994) is correct that the environmental crisis is 
grounded in mind, perception, and values, then efforts to promote students' perception skills seem of vital importance. Educational institutions have a special responsibility in this regard, "hence it is a challenge to those institutions presuming to shape minds, perceptions, and values” (p. 27). Recent studies (e.g., Brämer, Koll, \& Schild, 2016) indicate that young persons' presence in nature is diminishing. However, is not nature just the proper place to practice and improve students' listening competences?

My third topic concerns the relation between listening and the nature of nature. In sustainability education, Sandell and Öhman (2010) argue, instead of a static concept of nature, there is a need for a situated, dynamic and process-oriented one. Does an eco-acoustic understanding provide such an extended conception of nature? In the act of listening, there is the attentive listener on the one hand, and the sounding world on the other. I rephrase Evans' quote above in the following manner: Nature will not of itself speak to us - we must learn to read it. The ontological question we need to pose is: Exactly what is the character of nature when it speaks to us? What is the Aufforderingscharakter of nature, that is, how does nature invite our ears to search its sonic expressions? The concept of nature is disputed in current sustainability discourse. In order to avoid the term, and still describe the environment as something different than humans and culture, several concepts have been introduced, like for example the "more-than-humanlifeworld” (e.g., Kagan, 2011), “non-humans” (Pröpper, 2017), and “non-human systems/world” (Kagan \& Kirchberg, 2016; Turner \& Freedmann, 2004). Such characteristics might deepen the humans-nature division, in a time where students should be encouraged to seek nature connectedness. The problem is not primarily the specific term used, but the tendency to describe nature as that which is not human. How can students be expected to develop a caring, respectful relation to nature if all there is to care for is some more-than-human "out there"? This question is both an educational one as well as ontological one: If nature is being that speaks to us (Dahlin, Hugo, \& Østergaard, 2015), how can we (re-)learn to listen to its speech?

In every field of research, lots of new questions emerge. In this regard, the area of music and sustainability education is no exception. What interests me is the transfer values of such inquiries for art-science interdisciplinary work. Researching these three ideas presupposes an interest from disciplines like music, philosophy of science, education, ecology, and science to work together with commitment and mutual interest.

\section{Concluding remarks}

Learning to listen attentively is an attempt to overcome our deafness for the environment. My review of research literature in the field of music and sustainability education has led me to regard listening skills as complementary to the 
ability to let the environment present itself acoustically. The world comes to us as sound: sound "stimulates directly to immediate change because it reports a change" (Dewey, 2005, p. 246), sound brings to us "the very movement of the world's coming-into-being” (Ingold, 2000, p. 245). It is challenging to balance the value of listening at the cost of visuality:

More than any other modality of perception, they say, vision leads us to objectify our environment, to regard it as a repository of things, alien to our subjective selves, that are there to be seized by the eyes, analysed by science, exploited by technology, and dominated by power. If only we could redress the balance by restoring hearing to its proper place in the sensorium, it is claimed, we might hope to regain a more harmonious, benevolent and empathic awareness of our surroundings. (p. 246)

My central thesis in this inquiry is that attentive listening (in general) and music (in particular) have the potential of strengthening students' sensuous awareness and world engagement. I do think that enhanced listening is relevant for promoting sustainability and that music and art have roles to play when it comes to refreshing our sensuous awareness. The term "potential”, however, indicates that the ideas so far are on a wishful and visionary level and that there is a great lack of empirical research. Scholars like Böhme (2001), Dunn (1999), Ingold (2000), and Cage (1981) all point at the necessity of relearning to listen to the world as a prerequisite for world bonding. The emerging field of eco-acoustics and soundscape art contribute to expanding our awareness of the sounding ecology. This field represents a potential that for the most part is left untapped in sustainability education.

Unlike Cage, who rejects the possibility to use music to reinforce listening to the environment, I argue that the fact that musicians and music students are trained in listening, implies both a long educational tradition and personal experience that can be shared with other subjects. However, there is no obvious transferability of listening skills from music education to other school subjects. In current Norwegian music curricula, the skill of listening is described as "the experience of music and personal performance, alone and when playing with others", "listening to and playing music" (Udir, 2019a, p. 3), and students being able to "use basic techniques of listening" (Udir, 2019b, p. 3, my translation). These competence descriptions are all limited to a specific musical form of listening. Collaboration in sustainability education regarding attentive listening presupposes, however, a genuine interest from all teachers to apply listening as an interdisciplinary more-than-musical skill. It would be incorrect to conclude that the skill of the attentive ear is not transferable from music to other subjects as long as this has not been explored empirically (Østergaard, 2019).

My pondering on the initial question, whether there is a contradiction between music and sustainability, leaves me with several answers. I do see a great potential when it comes to a fruitful cooperation between sustainability education and music teaching - several of the reviewed research contributions point in this 
direction. Turner and Freedman (2004), for example, claim that music can enhance perceptions of the value of the natural world, "especially when nature itself is recognized as being musical” (p. 45). Further, Coss (2013) maintains that music education can be incorporated in curriculum development in sustainability education "to address the multi-cultural issues of the ecological crisis" (p. 23). However, in the reviewed research on music and sustainability, I find a latent tension between, on the one hand, those who regard music as a means for teaching for sustainability, and, on the other hand, those who view music as genuine knowledge that sustainability education is in need of. Only a few scholars take the second stance. One of them is Roger Coss who rings "a note of caution against articulating the role of music education in utilitarian terms" (p. 22). Perhaps the greatest fallacy is to reduce music to a tool to achieve sustainability goals. Then music's potential of opening up a world is lost. Music and art are ambiguous rather than goal-oriented. Music and art have the ability to "invite the unforeseen" (Boeckel, 2017), an ability that seems of vital importance in current sustainability discourse. We need fresh and unconventional ideas to cope with the present situation in a desirable future direction.

I argue that all school subjects should contribute to interdisciplinary efforts toward a sustainable future. However, because science education takes a leading role in sustainability discourse, and that for good reasons, the whole transdisciplinary project might become colored by natural scientific thought. Scientific research and the scientific attitude are "often bound by the sequential, rule-bound logics of science" (Gershon \& Ben-Horin, 2014, p. 7). Why does music take seemingly little ownership in interdisciplinary sustainability projects? Would sustainability projects look differently if artists and art teachers or musicians and music teachers had taken on a more active role? Such a shift of roles is indeed worth trying.

\section{About the author}

Edvin Østergaard is a composer and a professor in art and science in education at the Norwegian University of Life Sciences (NMBU). His research focuses on the interplay between art and science, with emphasis on educational aspects, and history and philosophy of science, with emphasis on aesthetics and the diversity of forms of knowing.

Institutional affiliation: Section for Learning and Teacher Education, Faculty of Science and Technology, NMBU, 1432 Ås, Norway.

E-mail: edvin.ostergaard@nmbu.no 


\section{References}

Bastian, H. G. (2000). Musik(erziehung) und ihre Wirkung. Eine Langzeitstudie an Berliner Grundschulen [Music (education) and ist impact. A longitudinal study in primary schools in Berlin]. Mainz: Schott.

Bellocchi, A., Quigley, C., \& Otrel-Cass, K. (Eds.) (2017). Exploring emotions, aesthetics and wellbeing in science education research. Basel: Springer.

Boeckel, J. v. (2013). At the heart of art and earth. An exploration of practices in arts-based environmental education. Helsinki: Aalto University publication series, Doctoral Dissertations 73/2013.

Boeckel, J. v. (2017). Artful empiricism and improvising with the unforeseen. In S. Asikainen et al. (Eds.), Culture in sustainability. Towards a transdisciplinary approach (pp. 143160). Jyväskylä: University of Jyväskylä.

Brämer, R., Koll, H., \& Schild, H. (2016). 7. Jugendreport Natur 2016. Natur Nebensache? [7th Youth Report Nature 2016. Nature a minor matter?]. Universität zu Köln. Retrieved 7 June 2018 from https://www.wanderforschung.de/files/jugendreport2016-web-final160914-v3_1609212106.pdf

Burnard, P., Dragovic, T., Jasilek, S., Biddulph, J., Rolls, L., Durning, A., \& Fenyvesi, F. (2017). The art of co-creating arts-based possibility spaces for fostering STE(A)M practices in primary education. In T. Chemi \& X. Du (Eds.), Arts-based methods in education around the world (pp. 247-281). Delft: River Publishers.

Böhme, G. (2001). Akustische Atmosphären. Ein Beitrag zur ökologischen Ästhetik [Acoustic atmospheres. A contribution to ecological aesthetics]. In Institut für Neue Musik und Musikerziehung (Ed.), Klang und Wahrnehmung [Sound and Sensing] (pp. 38-48). Mainz: Schott.

Cage, J. (1961). Silence. Middletown: Wesleyan University Press.

Cage, J. (1981). For the birds. Boston, London: Marion Boyars.

Clark, B. \& Button, C. (2011). Sustainability transdisciplinary education model: interface of arts, science, and community (STEM). International Journal of Sustainability in Higher Education, 12(1), 41-54.

Colucci-Gray, L. \& Camino, E. (2016). Looking back and moving sideways: following the Gandhian approach as the underlying thread for a sustainable science and education. Visions for Sustainability, 6, 23-44.

Coss, R. (2013). Multicultural perspectives through music \& sustainability education. Multicultural Education, 21(1), 20-25.

Dahlin, B., Hugo, A., \& Østergaard, E. (2015). The nature of nature: ontologies in learning science. In P. Kemp \& S. Frøland (Eds.), Nature in Education, Vol. 3 of "Philosophy of Education” (pp. 66-80). Zürich: LIT Verlag.

Dewey, J. (2005). Art as experience. London: Penguin Books.

Dunn, D. (1999). Why do whales and children sing? A guide to listening to nature. Santa Fe, NM: EarthEar (book and compact disc).

Erlmann, V. (2010). Reason and resonance. A history of modern aurality. New York: Zone Books.

Espinet, D. (2016). Phänomenologie des Hörens [The phenomenology of hearing]. Tübingen: Mohr Siebeck.

Evans, M. (1990). Listening to music. Swansea Studies in Philosophy. London: Macmillan Press.

Gasc, A., Francomano, D., Dunning, J. B., \& Pijanowski, B. C. (2017). Future directions for soundscape ecology: The importance of ornithological contributions. The Auk, 134(1), 215-228. 
Gershon, W. S. \& Ben-Horin, O. (2014). Deepening inquiry: What processes of making music can teach us about creativity and ontology for inquiry based science education. International Journal of Education \& the Arts, 15(19). Retrieved 13 June 2018 from https://www.scribd.com/document/248216225/International-Journal-of-Education-the$\underline{\text { Arts }}$

Gjøtterud, S. \& Krogh, E. (2017). The power of belonging. International Journal of Transformative Learning, 4(1), 7-17.

Glasser, H. \& Hirsh, J. (2016). Toward the development of robust learning for sustainability core competencies. Sustainability: The Journal of Record, 9(3), 121-134.

Hargreaves, D. J., Hargreaves, J. J., \& North, A. C. (2012). Imagination and creativity in music listening. In D. J. Hargreaves, D. E. Miell, \& R. A. R. MacDonald (Eds.), Musical imaginations. Multidisciplinary perspectives on creativity, performance, and perception (pp. 156-172). Oxford, UK: Oxford University Press.

Heidegger, M. (1962). Being and time (translated by J. Macquarrie \& E. Robinson). Oxford, UK: Basil Blackwell.

Ingold, T. (2000). The Perception of the environment. Essays on livelihood, dwelling and skill. London and New York: Routledge.

Ingram, D. (2006). 'A balance that you can hear': deep ecology, 'serious listening' and the soundscape recordings of David Dunn. European Journal of American Culture, 25(2), 123-138.

Jolly, L., Boeckel, J. van, \& Slåttli, S. (2017). Biology, art and sustainability. Artizein: Arts and Teaching Journal, 2(2), Article 7.

Kagan, S. (2011). Art and sustainability. Connecting patterns for a culture of complexity. Lüneburg: Leuphana University.

Kagan, S. (2012). Toward global (environ)-mental change: transformative art and cultures of sustainability. Publication series ecology, Vol. 20. Berlin: Heinrich-Böll-Stiftung.

Kagan, S. \& Kirchberg, V. (2016). Music and sustainability: organizational cultures towards creative resilience - a review. Journal of Cleaner Production, 135, 1487-1502.

Lutnæs, E. \& Falling, N. (2017). Bærekraftig utvikling gjennom skapende praksis. Utvikling av økoliteracy i et samlet kunst- og håndverksfag [Sustainable development through creative practice. Development of eco-literacy in a compiled arts and crafts subject]. FormAkademisk, 10(3), 1-19.

McNaughton, D., Hamlin, D., McCarthy, J., Head-Reeves, D., \& Schreiner, M. (2007). Learning to listen: Teaching an active listening strategy to preservice education professionals. Topics in Early Childhood Special Education, 27(4), 223-231.

Orr, D. W. (1994). Earth in mind. On education, environment, and the human prospect. Washington: Island Press.

Østergaard, E. (2017). Earth at rest. Aesthetic experience and students' grounding in science education. Science \& Education, 26(5), 557-582. doi: https://doi.org/10.1007/s11191017-9906-2

Østergaard, E. (2019). The attentive ear. Forthcoming in Journal of Aesthetic Education.

Peters, G. (2018). John Cage and the "freshening" of education. Journal of Aesthetic Education, 52(4), 1-20.

Pijanowski, B. C., Villanueva-Rivera, L. J., Dumyahn, S. L., Farina, A., Krause, B. L., Napoletano, B. M., Gage, S. H., \& Pieretti, N. (2011). Soundscape ecology: The science of sound in the landscape. BioScience, 61, 203-216.

Pröpper, M. H. (2017). Sustainability science as if the world mattered: sketching an art contribution by comparison. Ecology and Society, 22(3), Art. 31. doi:

https://doi.org/10.5751/ES-09359-220331 
Publicover, J. L., Wright, T. S., Baur, S., \& Duinker, P. N. (2018). Music as a tool for environmental education and advocacy: artistic perspectives from musicians of the Playlist for the Planet. Environmental Education Research, 24(7), 925-936. doi: https://doi.org/10.1080/13504622.2017.1365356

Ramsey, D. (2002). The role of music in environmental education: Lessons from the cod fishery crisis and the dust bowl days. Canadian Journal of Environmental Education, 7(1), 183-198.

Roth, W.-M. (2015). Enracinement or the earth, the originary ark, does not move: on the phenomenological (historical and ontogenetic) origin of common and scientific sense and the genetic method of teaching (for) understanding. Cultural Studies of Science Education, 10(2), 469-494.

Samkopf, K. (2010). Some thoughts on soundscape compositions. NoTAM Symposium 8-10 April 2010: Soundscape in the Arts. Retrieved 12 June 2018 from http://www.samkopf.no/pub/Soundscape.pdf

Sandell, K. \& Öhman, J. (2010). Educational potentials of encounters with nature: reflections from a Swedish outdoor perspective. Environmental Education Research, 16(1), 113-132.

Small, C. (1998). Musicking: the meaning of performing and listening. Wesleyan University Press: Middletown, CT.

Sterling, S. (2014). Separate tracks or real synergy? Achieving a closer relationship between education and SD, post-2015. Opinion Essay, Sage Publications, 8(2), 89-11.

Sterling, S., Glasser, H., Rieckmann, M., \& Warwick, P. (2017). „More than scaling up“: a critical and practical inquiry into operationalizing sustainability competencies. In P. B. Corcoran, J. P. Weakland, \& A. E. J. Wals (Eds.), Envisioning futures for environmental and sustainability education (pp. 153-168). Wageningen: Wageningen Academic Publishers.

Sueur, J. \& Farina, A. (2015). Ecoacoustics: The ecological interpretation of environmental sound. Biosemiotics, 8, 493-502.

Turner, K. \& Freedman, B. (2004). Music and environmental studies. The Journal of Environmental Education, 36(1), 45-52.

Udir (2019a). Curriculum for Music (MUS1-01). Oslo: Utdanningsdirektoratet. Retrieved 28 February 2019 from https://www.udir.no/kl06/MUS101?lplang=http://data.udir.no/kl06/eng

Udir (2019b). Loreplan i lytting - programfag i utdanningsprogram for musikk, dans drama, programområde for musikk (MDD3-01) [Curriculum for Listening - program subject for music, dance, drama, program area for music studies]. Oslo: Utdanningsdirektoratet. Retrieved 28 February 2019 from https://www.udir.no/kl06/MDD301?lplang=http://data.udir.no/kl06/nob

Udir (2019c). Natural Science Subject Curriculum (NAT1-03). Oslo: Utdanningsdirektoratet. Retrieved 28 Februar 2019 from https://www.udir.no/kl06/NAT103/Hele/Kompetansemaal/competence-aims-after-year-level7?lplang=http://data.udir.no/kl06/eng

UNESCO (2012). ESD sourcebook: Learning \& training tools (No. 4). Paris: UNESCO. Retrieved 12 June 2018 from http://unesdoc.unesco.org/images/0021/002163/216383e.pdf

Wiek, A., Withycombe, L., \& Redman, C. L. (2011). Key competencies in sustainability: a reference framework for academic program development. Sustainability Science, 6, 203218. 